Joanna Kaźmierczak ${ }^{1}$

http://dx.doi.org/10.18778/8088-306.2.03

\title{
Oddział spółki handlowej w roli pracodawcy
}

Sytuacja prawna spółek handlowych występujących na gruncie stosunków prawa pracy w roli pracodawców jest dość złożona. W przeciwieństwie do osób fizycznych zatrudniających pracowników, spółki (z wyjątkiem jednak spółki cywilnej), będąc podmiotami prawa cywilnego o złożonej strukturze, są uwikłane w różne problemy prawa pracy, których rozstrzygnięcie przekłada się na praktykę. Zagadnienia te dają się pogrupować w co najmniej trzy kategorie. Pierwsza grupa problemów odnosi się do ustalenia kryteriów decydujących o tym, jakie jednostki organizacyjne mogą występować w roli pracodawcy. W dalszej kolejności rozstrzygnięcia wymagać będzie prawidłowe ustalenie legitymacji czynnej w procesach pracowniczych z udziałem jednostek organizacyjnych występujących w roli pracodawców. Osobną problematyką jest natomiast osadzenie powyższych rozważań na gruncie regulacji prawnych odnoszących się do statusu oddziału przedsiębiorcy zagranicznego.

Zdolność do występowania w stosunkach pracy w charakterze pracodawcy określa art. 3 ustawy z dnia 26 czerwca 1974 r. Kodeks pracy (t. j. D.U. z 2014 r. poz. 1502 ze zm. zwany dalej w skrócie k.p.) statuujący zasadę, że pracodawcą jest jednostka organizacyjna, choćby nie posiadała osobowości prawnej, a także osoba fizyczna, jeśli zatrudniają one pracowników. Na wstępie należy wyjaśnić, że dość niefortunne określenie „jeśli zatrudniają one pracowników” nie jest interpretowane w doktrynie kategorycznie. Sens tego sformułowania polega na tym, że pracodawcą nie może być podmiot lub jednostka organizacyjna, która nie zatrudniała choćby jednego pracownika. Nawet po zakończeniu stosunku pracy były pracodawca nie traci wobec swojego byłego pracownika statusu pracodawcy. W większości przypadków z miana pracodawcy będzie jednak korzystać ten podmiot, który pozostaje aktualnie stroną istniejącego stosunku pracy. Definicja zdolności pracodawczej jest więc ujęta w kodeksie pracy bardzo szeroko. Przedstawiona definicja obejmuje zakresem zastosowania wszelkie możliwe jednostki organizacyjne, choćby niewyposażone w osobowość prawną.

${ }^{1}$ Absolwentka, Uniwersytet Łódzki, Wydział Prawa i Administracji. Adwokat. 
W roli pracodawcy może zatem występować każdy podmiot prawa cywilnego, włącznie $\mathrm{z}$ regulowanymi $\mathrm{w}$ art. $33^{1}$ Kodeksu cywilnego ${ }^{2}$ ułomnymi osobami prawnymi, określanymi jako jednostki organizacyjne niemające osobowości prawnej, którym ustawa przyznaje zdolność prawną. Jednakże, teza, w myśl której tylko istniejące podmioty prawa cywilnego wyposażone $\mathrm{w}$ zdolność prawną mogą być pracodawcą, nie wyczerpuje całości zagadnienia. Porównanie treści art. 3 k.p. $\mathrm{z}$ art. $33^{1}$ k.c. prowadzi do wniosku, że stroną stosunku pracy może być także jednostka, która nie ma zdolności prawnej. Art. $33^{1}$ k.c. stawia wymóg dla możności przypisania jednostce organizacyjnej zdolności prawnej. Asumpt do stwierdzenia, że jednostka organizacyjna ma zdolność prawną daje istnienie przepisu ustawy wyraźnie stwarzającego jej możność nabywania praw, zaciągania zobowiązań, pozywania i bycia pozywaną. Takie prawne umocowanie można odnaleźć np. w art. 8 Kodeksu spółek handlowych w odniesieniu do spółek osobowych lub w art. 6 ustawy o własności lokali3, odwołującym się do statusu prawnego wspólnot mieszkaniowych. Art. 3 k.p. nie powiela jednak przesłanki $\mathrm{z}$ art. $33^{1}$ k.c. Jest $\mathrm{w}$ nim mowa jedynie o jednostkach organizacyjnych, które nie mają osobowości prawnej. Ustawodawca nie zastrzegł przy okazji odwoływania się do pojęcia jednostek organizacyjnych niemających osobowości prawnej, że muszą być one wyposażone w zdolność prawną. W rezultacie konstrukcja definicji pracodawcy w kodeksie pracy jest niezwykle pojemna, odnosi się nie tylko do ułomnych osób prawnych, ale też do jednostek wewnętrznych osób prawnych, nie mających osobowości prawnej, ani zdolności prawnej, np. oddziałów osób prawnych lub ułomnych osób prawnych. Należy tę sytuację postrzegać jako wyjątkową. Okazuje się bowiem, że jednostka organizacyjna, która nie może działać samodzielnie jako podmiot stosunku prawnego w obrocie cywilnoprawnym sensu strico, będąc pozbawiona możności zawierania jakichkolwiek umów, może jednak funkcjonować jako strona stosunku pracy ${ }^{4}$. Dość przypomnieć, że np. oddział spółki handlowej nie może w imieniu własnym zawrzeć umów sprzedaży lub dostawy, może jednak - pod pewnymi warunkami, o czym dalej będzie mowa - zgodnie z prawem zatrudnić pracowników. W literaturze prawa pracy jednostki organizacyjne podmiotów prawa

\footnotetext{
2 Ustawa z dnia 23 kwietnia 1964 roku Kodeks cywilny, Dz.U. z 2016 r. poz. 380 ze zm. zwany dalej k.c.

${ }^{3}$ Ustawa z dnia 24 czerwca 1994 roku o własności lokali, Dz.U. z 2015 r. poz. 1892 ze zm.

${ }^{4}$ Wyrok Sądu Najwyższego z dnia 6 listopada 1991 roku, sygn. I PRN 47/91, OSP 1992 nr 7, str. 320; wyrok SN z dnia 6 czerwca 2012, sygn. III PK 81/11, Legalis nr 537282.
} 
niemające osobowości prawnej ani zdolności prawnej, choć zatrudniające pracowników, nazywa się pracodawcami wewnętrznymi ${ }^{5}$.

Powyższe wywody trzeba uzupełnić także o uwagę, że gdy chodzi o spółkę cywilną, która nie ma własnej podmiotowości prawnej, będąc zaledwie umową między co najmniej dwiema osobami fizycznymi, zdolność do bycia stroną stosunków pracy mają wszyscy wspólnicy spółki cywilnej łącznie. Nie ma także wyjątku od zasady, że wszyscy wspólnicy powinni dla skuteczności czynności prawnej uczestniczyć w składaniu oświadczenia woli o wstąpieniu w stosunek pracy, gdy jeden ze wspólników spółki cywilnej występowałby w imieniu innego wspólnika spółki, wyrażając za niego wolę zawarcia umowy. Reprezentowany wspólnik, jedynie fizycznie nieobecny, składałby własne oświadczenie woli przez swojego pełnomocnika. W braku oświadczeń woli, które pochodziłyby od wszystkich wspólników, umowę należałoby oceniać jako niezawartą. Spółka cywilna powinna być pominięta w tej części rozważań doktryny, które dotyczą zdolności jednostek wewnętrznych do bycia pracodawcą, bo podmiotami mogącymi działać w roli pracodawców będą tylko wszyscy wspólnicy, niezależnie od tego, gdzie prowadzą oni działalność gospodarczą i bez względu na to, czy miejsc tych jest więcej niż jedno, czy nie. W rezultacie można uznać, że status spółki cywilnej występującej w roli pracodawcy nie różni się od statusu osoby fizycznej działającej jako pracodawca. W dalszych rozważaniach spółka cywilna jest pominięta, jako że nie stanowi jednostki organizacyjnej.

W realiach obrotu powstaje pewnego rodzaju konkurencja między wyodrębnionymi jednostkami organizacyjnymi o możliwość przypisania im zdolności pracodawczej. O ile nie będzie wątpliwości, jaki podmiot występuje $\mathrm{w}$ roli pracodawcy $\mathrm{w}$ przypadku podmiotów o strukturze jednolitej, nie mających wyodrębnionych wewnętrznych jednostek organizacyjnych, o tyle komplikacje i ryzyko popełnienia błędów pojawiać się będą wtedy, gdy potencjalnie dwie jednostki organizacyjne będą mogły być pracodawcami, np. osoba prawna i jej oddział. Kryteria określone w art. 3 k.p. z uwagi na ich ogólnikowość będą bowiem spełniały nie tylko wszystkie spółki handlowe jako takie, ale ponadto ich wyodrębnione struktury wewnętrzne. Jako że prawo pracy nie dopuszcza możliwości podziału statusu pracodawcy na dwie lub więcej jednostki organizacyjne, konieczne staje się za każdym razem

\footnotetext{
5 P. Korus, Pojęcie pracodawcy, [w:] Kodeks pracy. Komentarz pod red. A. Sobczyka, Warszawa 2015, s. 9.
} 
precyzyjne wskazanie, kto występuje $\mathrm{w}$ danym stosunku pracy w charakterze pracodawcy. Rozstrzygnięcie tej kwestii daje impuls dla podjęcia dalszych rozważań doktryny i praktyki.

Pod pojęciem oddziału spółki rozumie się w świetle art. 5 pkt. 4 ustawy o swobodzie działalności gospodarczej ${ }^{6}$ wyodrębnioną i samodzielną organizacyjnie część działalności gospodarczej wykonywaną przez przedsiębiorcę poza siedzibą przedsiębiorcy lub głównym miejscem wykonywania działalności. Definicje oddziału spółki wprowadzał art. 2 ust. 1 pkt. 6 ustawy o działalności ubezpieczeniowej oraz przepisy ustawy prawo bankowe ${ }^{8}$. Powołane $\mathrm{w}$ dalszej kolejności regulacje mają jednak charakter lex specialis i nie zmieniają założeń zasadniczego unormowania z ustawy o swobodzie działalności gospodarczej. Oddział spółki krajowej jest w znaczeniu organizacyjnym i gospodarczym osobnym tworem, choć w sensie podmiotowym stanowi część spółki, nie posiadającym własnej zdolności prawnej, zdolności do czynności prawnych, a także jest zasadniczo pozbawiony zdolności sądowej i rejestracyjnej'. Ujawnieniu w Krajowym Rejestrze Sądowym nie podlega bowiem oddział krajowej spółki handlowej w charakterze osobnego podmiotu prowadzącego działalność gospodarczą. Oddział spółki krajowej może figurować w rejestrze przedsiębiorców wyłącznie jako część przedsiębiorcy. W konsekwencji oddział spółki mającej siedzibę na terytorium Rzeczpospolitej Polski nie posiada statusu przedsiębiorcy, zaś jego działalność ma charakter zależny wobec podmiotu, który współtworzy. Działanie oddziału spółki prowadzić może jedynie do nabycia praw lub zaciągnięcia zobowiązań przez przedsiębiorcę ${ }^{10}$. Co do zasady nie może on nabywać własnych praw i zaciągać własnych zobowiązań. Choć zazwyczaj oddział spółki krajowej prowadzi własną księgowość, jest wyposażony w majątek i osobne kierownictwo, pozostaje ściśle związany z działalnością przedsiębiorcy, którego współtworzy. Nie należy też wyciągać zbyt daleko idących wniosków z regulacji

6 Ustawa z dnia 2 lipca 2004 roku o swobodzie działalności gospodarczej, Dz.U. z 2015 r. poz. 584 ze zm.

${ }^{7}$ Ustawa z dnia 22 maja 2003 roku o działalności ubezpieczeniowej, Dz.U. z 2015 r. poz. $1348 \mathrm{ze} \mathrm{zm}$.

8 Ustawa z dnia 29 sierpnia 1997 roku prawo bankowe, Dz.U. z 2015 roku, poz. 128 ze zm.

${ }_{9}^{9}$ Postanowienie Sądu Najwyższego z dnia 9 maja 2007 roku, sygn. akt II CSK 25/07, OSNC 2008 nr 5, poz. 52, str. 86; postanowienie Sądu Najwyższego z dnia 8 maja 2013 roku, sygn. akt I CZ 34/13, OSNC 2014, poz. 7, str. 50.

10 P. Pawlonka, Oddział przedsiębiorcy w procesie cywilnym, „Monitor Prawniczy”, nr 13/2010, s. 731. 
właściwości przemiennej z art. 33 Kodeksu postępowania cywilnego ${ }^{11}$. Oddział spółki lub zakład nie nabywają na jego podstawie zdolności sądowej w sprawach majątkowych przeciwko przedsiębiorcy. Przepis ten należy interpretować wyłącznie $\mathrm{w}$ znaczeniu technicznym, mającym na celu ułatwienie stronie przeciwnej względem przedsiębiorcy pozywanie go w sprawach o roszczenia majątkowe.

Na tle tak jednoznacznej linii orzeczniczej i poglądów doktryny w przedmiocie braku podmiotowości prawnej oddziału spółki krajowej wyjaśnienia wymaga zjawisko i zasady autonomicznego funkcjonowania tych jednostek organizacyjnych w obrocie prawa pracy. W pierwszej kolejności pojawia się problem prawnego umocowania oddziałów spółek do działania we własnym imieniu jako strona stosunku pracy. Jakie regulacje wewnętrzne powinny zostać podjęte przez spółkę, aby można było uznać, że oddział spółki został wyposażony w prawo działania w imieniu własnym na gruncie stosunków prawa pracy? Teoretycznie możliwych jest kilka rozwiązań. Można byłoby przyjąć, że zarząd spółki lub inny organ wykonawczy podejmowałby uchwałę zezwalającą oddziałowi na zatrudnianie pracowników we własnym imieniu. Inne prawdopodobne rozwiązanie mogłoby polegać na udzieleniu upoważnienia kierownictwu oddziału do zawierania stosunków pracy. Upoważnienie oddziału mogłoby także czerpać źródło w woli organu uchwałodawczego spółki, tj. w woli wspólników, wyrażonej w formie oraz czyniącej zadość większości wymaganej przez akt założycielski do podjęcia uchwały.

Upoważnienie kierownictwa oddziału spółki nie stwarza mu możliwości samodzielnego działania. Ewentualna czynność prawna upoważniająca kierownictwo do zawierania umów o pracę tworzyłaby jedynie relację prawną między spółką a osobą upoważnioną, pozostając bez wpływu na całokształt uprawnień służących jednostce wewnętrznej spółki. W rezultacie umowy zawarte na podstawie takiego upoważnienia byłyby de facto umowami ze spółką, a działanie kierownictwa byłoby interpretowane jako reprezentacja spółki. Uprawnienie kierownika $\mathrm{w}$ takim przypadku odpowiadałoby prawom prokurenta spółki.

W orzecznictwie i piśmiennictwie przyjmuje się prymat stanowiska, zgodnie z którym umocowanie oddziału spółki do działania we własnym imieniu na gruncie prawa pracy powinno zostać udzielone wyraźnie w akcie wewnętrznym spółki, zatem powinno pochodzić od

11 Ustawa z dnia 17 listopada 1964 roku Kodeks postępowania cywilnego, Dz.U. z 2014 r. poz. 101 ze zm., zwana dalej k.p.c. 
jej wspólników ${ }^{12}$. Tytułem przykładu do takich regulacji wylicza się: akt powołujący do życia spółkę (statut lub umowa) lub inną jednostkę organizacyjną lub wewnętrzny regulamin organizacyjny podmiotu. Jeśli chodzi o państwowe jednostki organizacyjne Skarbu Państwa i jednostki samorządowe, autonomia jednostki wewnętrznej może być zastrzeżona w ustawie. W odniesieniu do Skarbu Państwa nasuwa się wszakże uwaga, że jest to jedyny podmiot wyposażony w osobowość prawną, który nie będzie występować w roli pracodawcy, gdyż w jego imieniu w ramach sektora państwowego pracodawcami będą staciones fisci ${ }^{13}$. Jako egzemplifikację tej tezy można by podać uchwałę Sądu Nawyższego z dnia 23 maja 1993 roku$^{14}$, w której stwierdza się, że w roli pracodawcy dla osób zatrudnionych w sądach i prokuraturach nie jest państwo ani Ministerstwo Sprawiedliwości, ale konkretny sąd lub prokuratura ${ }^{15}$. W każdym jednak przypadku wymaga się wyraźnego merytorycznego umocowania w akcie powołującym jednostkę do działania autonomicznie względem podmiotu, który oddział współtworzy.

Jednakże przyznanie możliwości samodzielnego zatrudniania pracowników, aby było skuteczne, powinno być zwieńczeniem wyodrębnienia oddziału. Sam fakt wypracowania przez jednostkę wewnętrzną względnej autonomii majątkowej lub finansowej i organizacyjnej nie wystarcza, aby mogła ona być pracodawcą ${ }^{16}$. Podobnie fakt wypłacania wynagrodzeń za pracę pracownikom zatrudnionym przez spółkę nie będzie powodować, że oddział stanie się wskutek tych działań stroną umowy o pracę ${ }^{17}$. Należy mieć też na uwadze, że bez odrębności i wystarczającej samodzielności jednostki wewnętrznej nie byłoby w ogóle możliwe znalezienie innego niż spółka potencjalnego podmiotu działającego jako strona stosunku pracy. Przesłanka wystarczającej autonomiczności oraz umocowanie do działania w imieniu spółki powinny być spełnione kumulatywnie, żeby było możliwe rozważanie nadania określonej jednostce statusu pracodawcy.

\footnotetext{
12 Wyrok Sądu Najwyższego z dnia 7 maja 2013 roku I PK 282/12, Legalis 747311.

13 T. Liszcz, Prawo pracy, LexisNexis 2009, s. 105.

14 Uchwała Sądu Najwyższego z dnia 23 maja 1993 roku sygn. I PZP 30/93, OSNCP nr 6, poz. 123.

15 Wyrok Sądu Najwyższego z dnia 19 września 1996 roku, I PRN 101/95, OSNAPiUS $1997 \mathrm{nr} 7$ poz. 112.

16 Wyrok Sądu Apelacyjnego w Katowicach z dnia 22 stycznia 2013 roku, sygn. III AUa 638/12, Legalis 719402.

17 Wyrok Sądu Najwyższego z dnia 1 lutego 2000 roku, sygn. I PKN 494/99, OSNAPiUS 2001, nr 12, poz. 409.
} 
Powyższe otwiera kolejne szerokie pole do rozważań nauki prawa pracy. W doktrynie kontrowersje budzi kwestia, w jakie kryteria decydują o wyodrębnieniu oddziału spółki. T. Liszcz stoi na stanowisku, że wyodrębnienie majątkowe przejawia się co najmniej w wydzieleniu środków na fundusz płac i fundusz socjalny i w prawie swobodnego zarządzania tymi funduszami ${ }^{18}$. Na ogół wymaga się co najmniej wyodrębnienia organizacyjnego i finansowego. Nie stawia się natomiast jako warunek zdolności pracodawczej kryterium posiadania własnego majątku. Nie jest to jednak stanowisko jednolite, albowiem Sąd Najwyższy w wyroku z dnia 24 lutego 2015 roku ${ }^{19}$, odwołując się do literatury prawa pracy, stwierdził, że wystarczające dla zdolności pracodawczej jest wyodrębnienie organizacyjne oraz umocowanie do samodzielnego działania. $\mathrm{W}$ uzasadnieniu zaznaczono, że przypadki wyodrębnienia majątkowego będą rzadsze, gdyż na ogół jednostki organizacyjne nie są właścicielami mienia, które należy bezpośrednio do spółki lub innego podmiotu, który jednostka współtworzy. Trzeba jednak zauważyć, że czym innym jest osobne źródło finansowania, czym innym zaś posiadanie własnego majątku. Nie trzeba być właścicielem mienia, aby móc gospodarować własnymi środkami pieniężnymi, co jest jednoznaczne $\mathrm{z}$ autonomią finansową.

Trzeba jednak zaznaczyć, że kwalifikacja jednostki wewnętrznej spółki jako spełniającej kryteria zastrzeżone dla oddziału, wyrażone w art. 2 ust. 1 pkt. 6 ustawy o swobodzie działalności gospodarczej sugeruje, że jednostka ma wystarczającą odrębność, aby zachować swobodę kreowania stosunku pracy. Jeśli bowiem do przesłanek warunkujących stwierdzenie, że jednostka jest oddziałem należy m. in. odrębność i samodzielność organizacyjna i wykonywanie działalności poza siedzibą przedsiębiorcy lub głównym miejscem jej prowadzenia, już na etapie subsumpcji danej jednostki pod pojęcie oddziału stwierdza się jego niezbędną autonomię. Z reguły także prowadzenie działalności w pewnej odległości od głównego miejsca albo siedziby stanowi impuls dla wytworzenia się wystarczającej samodzielności jednostki. Skoro działalność znajduje się w pewnej odległości od siedziby lub zakładu głównego ekonomia zarządzania skłania do wypracowania indywidualnych źródeł finansowania i własnej organizacji pracy. Zwykle będzie wówczas spełnione także kryterium osobnego źródła finansowania.

\footnotetext{
18 T. Liszcz, Prawo..., s. 107

19 Wyrok Sądu Najwyższego z dnia 24 lutego 2015 roku, sygn. akt II PK 88/14, Legalis 1242118.
} 
Wyjątkowe rozwiązania odnoszące się do zdolności pracowniczej jednostek wewnętrznych ustawodawca przenosi na grunt prawa procesowego. Art. $460 \S 1$ k.p.c. stanowi, że każda jednostka organizacyjna będąca pracodawcą $w$ rozumieniu art. 3 k.p. ma zdolność sądową, chociażby nie miała osobowości prawnej. Podobnie jak w przypadku zdolności prawnej tych jednostek legislator zdecydował się na ukształtowanie swoistej warunkowej konstrukcji zdolności sądowej, dodatkowo ograniczonej do spraw z zakresu prawa pracy. Powyższa regulacja ma niezwykłe znaczenie $\mathrm{w}$ praktyce. Nieprawidłowe oznaczenie podmiotu, który bierze udział $\mathrm{w}$ procesie pociąga za sobą daleko idące konsekwencje. Na etapie badania braków formalnych pozwu błędne wskazanie jednostki, która nie ma zdolności sądowej w sprawach pracowniczych skutkuje odrzuceniem pozwu w trybie art. 199 § 1 pkt 3 k.p.c. W dalszym stadium postępowania następującym po zbadaniu braków formalnych, nawet po prawomocnym rozstrzygnięciu sprawy przez sąd drugiej instancji mylne pozwanie jednostki, która nie może mieć zdolności sądowej na mocy art. 460 § 1 k.p.c. stwarza niebezpieczeństwo podniesienia zarzutu nieważności na podstawie art. 379 pkt 2 k.p.c. W nieco bardziej skomplikowanej konfiguracji, w której doszłoby do prawidłowego oznaczenia jako pozwanego spółki, która jednak nie brałaby udziału w procesie, w którym uczestniczyłaby jej jednostka wewnętrzna, zarzut przysługujący pozwanemu opierałby się na nieważności postępowania $\mathrm{z}$ powodu pozbawienia możności obrony swych praw na zasadzie art. 379 pkt 5 k.p.c. Ostatnie z możliwych zagrożeń przybierałoby postać orzeczenia sądu oddalającego powództwo - w razie gdy powód wytoczyłby pozew przeciwko podmiotowi, który co prawda ma zdolność sądową, lecz któremu nie przysługiwałaby legitymacja bierna, np. $z$ uwagi na fakt, że nie był pracodawcą w ramach stosunku prawnego, z którego powód wywodzi roszczenie (np. powód pozywa oddział spółki, mimo że łączy go stosunek pracy ze spółką lub na odwrót).

Przedstawiony kształt uregulowania zdolności do zatrudniania pracowników odpowiada koncepcji zarządczej pracodawcy. W skrócie można scharakteryzować ją jako uzależniającą podmiotowość pracodawczą tylko od ustalenia, kto faktycznie organizuje pracę, w oderwaniu od istniejących stosunków własnościowych lub majątkowych. Antagonistycznym do modelu zarządczego pracodawcy jest ujęcie pracodawcy jako podmiotu właścicielskiego, dominujące w regulacjach państw zachodnioeuropejskich. W drugiej koncepcji o statusie pracodawcy 
decyduje tytuł prawny do przedsiębiorstwa i jego majątku. Wyniku rozumowania nie mogą zmienić rzeczywiste regulacje w sferze organizacji pracy i zarządzania ${ }^{20}$.

Prawo pracy stawia mniejsze wymogi względem potencjalnych pracodawców niż te, które wynikałyby z ogólnych zasad obrotu cywilnego. Zarówno w przypadku osób fizycznych jak i w odniesieniu do jednostek organizacyjnych niewyposażonych $\mathrm{w}$ osobowość prawną i w zdolność prawną nie przewiduje się wymogu posiadania pełnej zdolności do czynności prawnych. O ile w przypadku osób fizycznych niemających zdolności do czynności prawnych ${ }^{21}$ lub ograniczonych w zdolności do czynności prawnych niezbędne do wykonywania praw i obowiązków ze stosunków pracy jest współdziałanie przedstawiciela ustawowego osoby niemającej pełnej zdolności do czynności prawnych, o tyle w przypadku oddziału spółki krajowej jest konieczne istnienie stosownego umocowania ze strony przedsiębiorcy. W obu przypadkach osoby fizyczne i oddziały nie mogą działać bez uprzedniego uzyskania zezwolenia, przy czym w odniesieniu do oddziału spółki przybiera ono swoistą formę. Dostrzegalne są jednak dwie zasadnicze różnice w statusie prawnych osób niemających pełnej zdolności do czynności prawnych i oddziałów działających w roli pracodawców. Oddział krajowej spółki, jeśli otrzyma w akcie wewnętrznym odpowiednie umocowanie do działania, może samodzielnie poruszać się w sferze stosunków pracy, przeciwnie do osób fizycznych niemających pełnej zdolności do czynności prawnych, które za każdym razem, gdy będą chciały dokonać czynności prawnej, będą musiały uzyskać zgodę przedstawiciela ustawowego pod rygorem uznania czynności dwustronnej za dotkniętą sankcją bezskuteczności zawieszonej. Jego zezwolenie na zawarcie umowy o pracę nie będzie umożliwiało osobie fizycznej pozbawionej pełnej zdolności do czynności prawnej dalszego samodzielnego postępowania jako pracodawca. Odnośnie do tych osób działają zasady ogólne od art. 10 k.c. do art. 22 k.c. w zw. z art. 300 k.p.

Zachowując wszelako pewną ostrożność, można zaproponować konkluzję, że oddział krajowej spółki korzysta ze zdolności prawnej spółki. Sam nie mając tej zdolności na wyłączność, może działać o tyle, o ile spółka wyposaży go w atrybuty umożliwiające mu działanie, co może nastąpić tylko w granicach zdolności prawnej spółki i tylko

\footnotetext{
20 K. Rączka Definicja pracodawcy, [w:] Kodeks Pracy. Komentarz pod red. M. Gersdorf, Warszawa wyd. III, LexisNexis 2014, s. 24; T. Liszcz, Prawo..., s. 111.

${ }^{21} \mathrm{~W}$ doktrynie prawa pracy istnieje spór, czy osoby niemające zdolności do czynności prawnych mogą mieć status pracodawcy (por. T. Liszcz, Prawo..., s. 110-112; M. Gersdorf, Kodeks pracy. Komentarz, wyd. III).
} 
w zakresie stosunków prawa pracy. W pozostałych sferach prawa oddział krajowej spółki nie korzysta z prawnej autonomiczności. Zdolność prawną oddziału spółki można w tym kontekście określić jako warunkową i ograniczoną.

Artykuł 3 k.p. wprowadza regulację o charakterze lex specialis $\mathrm{w}$ stosunku do zasadniczych unormowań kodeksu cywilnego w zakresie możności występowania w stosunkach pracy przez jednostki organizacyjne pozbawione osobowościi zdolności prawnej. W ślad za rozwiązaniami prawa materialnego podąża prawo procesowe, w którym nadaje się jednostkom wewnętrznym spółek zdolność sądową $w$ sprawach pracowniczych, mimo że co do zasady w obrocie cywilnoprawnym zdolność prawna im nie służy. Wydaje się, że analizowane rozwiązanie ma na celu zwiększenie zakresu zastosowania przepisów kodeksu pracy i ostatecznie intencją ustawodawcy jest ochrona interesów osób zarobkujących. W miarę jak rozszerza się zakres zastosowania przepisów prawa pracy, osoby świadczące pracę mogą korzystać ze szczególnych uprawnień pracowniczych, jakie nie są dostępne dla osób utrzymujących się z zysków wypracowanych w ramach wykonywania umów cywilnoprawnych. 